\title{
Dormancy release of wild barley seed germination by using plant growth regulators
}

\author{
Mohammad Majidi ${ }^{1}$, Mansour Taghvaei $^{1 *}$, Gholamreza Heidari ${ }^{2}$, Mohsen Edalat ${ }^{1}$, \\ Yahya Emam ${ }^{1}$
}

\author{
${ }^{1}$ Department of Crop Production and Plant Breeding, Shiraz University, Iran \\ ${ }^{2}$ Department of Agronomy and Plant Breeding, University of Kurdistan, Iran \\ ${ }^{\star}$ Corresponding author, E-mail: taghvaei@shirazu.ac.ir
}

\begin{abstract}
Plant growth regulators play an important role in control of seed germination. This experiment was conducted to investigate the effect of lant growth regulators (indole-3-acetic acid, gibberellin and kinetin) on seed germination of Hordeum spontaneum. Seeds of wild barley were soaked in distilled water (control) or different concentrations of gibberellin $\left(25,50,75,100,125\right.$ and 150 mg L $\mathrm{L}^{-1}$ ), indole-3-acetic acid and kinetin $\left(5,10,15,20,25\right.$ and $\left.30 \mathrm{mg} \mathrm{L}^{-1}\right)$. The following germination parameters were determined: germination percentage, germination index, mean germination time, germination energy, germination value, seedling length and seed vigour index. The results showed that plant growth regulators, depending on the used concentration, effectively improved all germination parameters except the mean rate of germination, which was increased only by indole-3-acetic acid at concentrations of 20 and $25 \mathrm{mg} \mathrm{L}^{-1}$. Gibberellin was generally shown to be more effective on all evaluated traits except the mean rate of germination. The highest values in germination percentage, germination index, germination energy, germination value, seed vigor index were obtained by using gibberellin at 75 mg $\mathrm{L}^{-1}$ and followed by $100 \mathrm{mg} \mathrm{L}^{-1}$. Gibberellin also at concentration of 50 and $125 \mathrm{mg} \mathrm{L}^{-1}$ led to the greatest mean germination time and seedling length, respectively.
\end{abstract}

Key words: germination, Hordeum spontaneum, plant growth regulator, seeds, wild barley.

Abbreviations: ABA, abscisic acid; GE, germination energy; GI, germination index; GP, germination percentage; GV, germination value; IAA, indole-3-acetic acid; MGT, mean germination time; MRG, mean rate of germination; PGR, plant growth regulator; SVI, seed vigour index.

\section{Introduction}

Wild barley (Hordeum spontaneum [K. Koch] Thell.) is a weedy winter annual, dominantly self-fertilizing diploid plant species from the Poaceae family. Wild barley is known to have been used in Neolithic food production in the Near East. Wild barley is considered as the progenitor of cultivated barley (Hordeum vulgare subsp. vulgare L.) and is a part of the primary gene pool with valuable sources of beneficial genes and largely unexploited resources for improving the narrowing genetic base of cultivated barley (Nevo 1992; Fu, Horbach 2012).

Seed dormancy is a mechanism that can be described as the inability of an intact, viable and mature seed to complete germination under optimal conditions (Linkies, LeubnerMetzger 2012). This mechanism helps the plant to adapt the timing of germination to the surrounding environmental conditions to prevent germination during seasons with unsuitable ecological conditions for the subsequent seedling establishment and plant growth (Linkies, LeubnerMetzger 2012). Dormancy can be caused by different seed tissues, such as embryo, endosperm or seed coat (Linkies, Leubner-Metzger 2012).
In wild barley, dormancy is much stronger than in cultivated barley, and freshly harvested caryopses of wild barley do not germinate in a range of temperatures $\left(10,20\right.$ and $\left.30^{\circ} \mathrm{C}\right)$, in continuous white light or darkness (Gutterman et al. 1996). Primary dormancy in wild barley seeds is caused by covering structures (glumellae as seed covering tissue and pericarp) (Gutterman et al. 1996; Gutterman, Gozlan 1999). The dormancy seems to be largely due to the increased abscisic acid (ABA) diffusion from the seed (Wang 1997). It has been proposed that the covering structures of the seed may reduce the availability of oxygen to the embryo and prevent germination (Gutterman 1996). Moreover, hypoxia condition may also interfere with ABA activity in the seed (Bench-Arnold et al. 2000). It has been found that the removal of glumellae and husk or afterripening greatly increased the seed germination even in low $\mathrm{O}_{2}$ conditions (Gutterman et al. 1996; Wang 1997). Thus, wild barley seeds require after-ripening for breaking of dormancy; this usually occurs during storage in dry conditions at $35^{\circ} \mathrm{C}$ or in the natural habitat during summer (Gutterman 1996). Seed dormancy and germination are regulated by interaction of plant hormones. Afterripening leads to changes in seed hormone content and/or 
sensitivity (Liu et al. 2013). Similarly, it has been suggested that the balance between $\mathrm{ABA}$ and gibberellin (GA) is a major regulator of seed dormancy and germination in cereal, Arabidopsis thaliana and other species (Bradford et al. 2008). In this case, GA and ABA have antagonistic action; GA breaks dormancy and promotes germination while $\mathrm{ABA}$ maintains dormancy and inhibits germination (Chaudhuri et al. 2013). It has been shown that the ABA content in barley embryos was greater in a more dormant variety than in a less dormant variety (Bradford et al. 2008).

The effects of other PGRs, such as brassinosteroids, ethylene, cytokinins, salicylic acid (Kucera et al. 2005; Wang, Irving 2011), jasmonate and auxin (Liu et al. 2013) on the regulation of seed physiological processes have been previously investigated.

High degree of dormancy in wild barley can have a negative effect on the rate and uniformity of germination and also ultimately causing poor seedling establishment. Furthermore, these flaws could hinder their application in breeding programs for cultivated barley. The available data about the effect of PGRs on germination of wild barley seeds are scarce and most studies are mainly limited to cultivated barley (Jacobsen et al. 2002; Gubler et al., 2008). The present investigation was designed to study the effect of different PGRs (indole-3-acetic acid, gibberellic acid and kinetin) on seed germination of wild barley.

\section{Materials and methods}

The experiment was conducted in Laboratory of Faculty of Agriculture, University of Kurdistan. Caryopses of wild barley Hordeum spontaneum were harvested on 23 July 2015 from the Experimental Station Farm of Kurdistan University. In order to maintain dormancy, wild barley seeds were stored at $5{ }^{\circ} \mathrm{C}$, for a period of 6 months (Shahmoradi et al. 2014).

The seeds were surface sterilized after washing with tap water for $1 \mathrm{~h}$ in $1 \%$ sodium hypochloride follwed by three washes with sterile distilled water for $5 \mathrm{~min}$. To determine the effect of PGRs on overcoming dormancy, 25 seeds were placed in Petri dishes $(90 \mathrm{~mm}$ ) on filter paper (Whatman No. 1) moistened with test solution (distilled water or different concentrations of PGRs). The treatments included a control (distilled water) and treatments with gibberellic acid $\left(\mathrm{GA}_{3}, 25,50,75,100,125\right.$ and $\left.150 \mathrm{mg} \mathrm{L}^{-1}\right)$, indole-3acetic acid and kinetin $\left(5,10,15,20,25\right.$ and $\left.30 \mathrm{mg} \mathrm{L}^{-1}\right)$. The above mentioned concentrations were obtained by dissolving of appropriate amounts of respective substances in $1 \mathrm{~mL}$ of $1 \mathrm{M} \mathrm{NaOH}$, and final volume was made up to 100 $\mathrm{mL}$ with distilled water, followed by filter sterilization, and stored at $4{ }^{\circ} \mathrm{C}$. During germination, filter papers were kept moist with the above mentioned solutions. The experiment was carried out for eight days at $20 \pm 2{ }^{\circ} \mathrm{C}$, relative humidity of 55 to $65 \%$ and continuous darkness in a growth chamber. The number of germinated seeds was recorded daily to determine the required time to achieve the final number of germinated seeds. Seed germination was recorded when the radicle was approximately $2 \mathrm{~mm}$ long or more (Rahimi et al. 2013). The germination parameters were calculated by the following formulas.

Germination percentage $(\mathrm{GP})=n / N \times 100$,

where $n$ is a number of seeds germinated, $N$ is a total number of seeds (Mousavizadeh et al. 2013).

Germination index $(\mathrm{GI})=\Sigma(n i / t i)$,

where $n i$ is a mumber of germinated seeds in a specified interval, $t i$ is a number of days after germination (Shahmoradi et al. 2014).

Mean germination time $($ MGT $)=\Sigma(n i \times t i) / \Sigma \mathrm{n}$, where $n i$ is a number of germinated seeds in a specified interval, $t i$ is a number of days after germination, $n$ is a number of seeds planted (Shahmoradi et al. 2014).

Mean rate of germination $(\mathrm{MRG})=1 / \mathrm{MGT}$ (Gholinejad 2012).

Germination energy $(\mathrm{GE})=\mathrm{Mng} / N \times 100$,

where $M n g$ is a maximum cumulative percentage of germinated seeds, $N$ is a number of seeds planted (Ahmadloo et al. 2009).

Germination value $(\mathrm{GV})=$ peak value $\times$ germination $\%$, where peak value is cumulative percent germination on each day/number of days elapsed since initial imbibition (Ramana et al. 2002).

Seed vigour index $(\mathrm{SVI})=L s \times P g / 100$,

where $L s$ is average length of seedling, $P g$ is germination percentage (Ghalmbaz, Fateh 2011).

Seedling length was measured for all germinated seeds on the $8^{\text {th }}$ day of the germination test. Also, at the end of the germination test, dry weight of seedlings were determined after oven drying at $70{ }^{\circ} \mathrm{C}$ for $48 \mathrm{~h}$.

The experiment was established in a completely randomized design with four replications. Data were analyzed using the MSTATC program and the mean values were compared by Duncan's test at $p \leq 0.05$.

\section{Results}

All concentrations of used PGRs effectively increased germination of $H$. spontaneum seeds (Table 1). Among all treatments, the highest GP (64 and 62\%) was obtained in 75 and $100 \mathrm{mg} \mathrm{L}^{-1} \mathrm{GA}_{3}$ treatments, respectively. The lowest GP (5\%) were recorded in the control treatment. $\mathrm{GA}_{3}$ at 75 and $100 \mathrm{mg} \mathrm{L}^{-1}$, IAA at $10 \mathrm{mg} \mathrm{L}^{-1}$ and kinetin at 10 and $15 \mathrm{mg} \mathrm{L}^{-1}$ were more effective to increase GP than other concentrations, and increasing PGR concentration led to a decline in GP (Table 1).

$H$. spontaneum GI was significantly $(p<0.01)$ affected by the treatments (Table 1). Soaking of seeds in all doses of PGRs significantly increased the GI, compared with control treatment. In addition, the highest GI (3.94 and 3.75) was obtained by applying 75 and $100 \mathrm{mg} \mathrm{L}^{-1} \mathrm{GA} 3$, respectively. The optimum PGR doses to achieve maximum rate of GI 


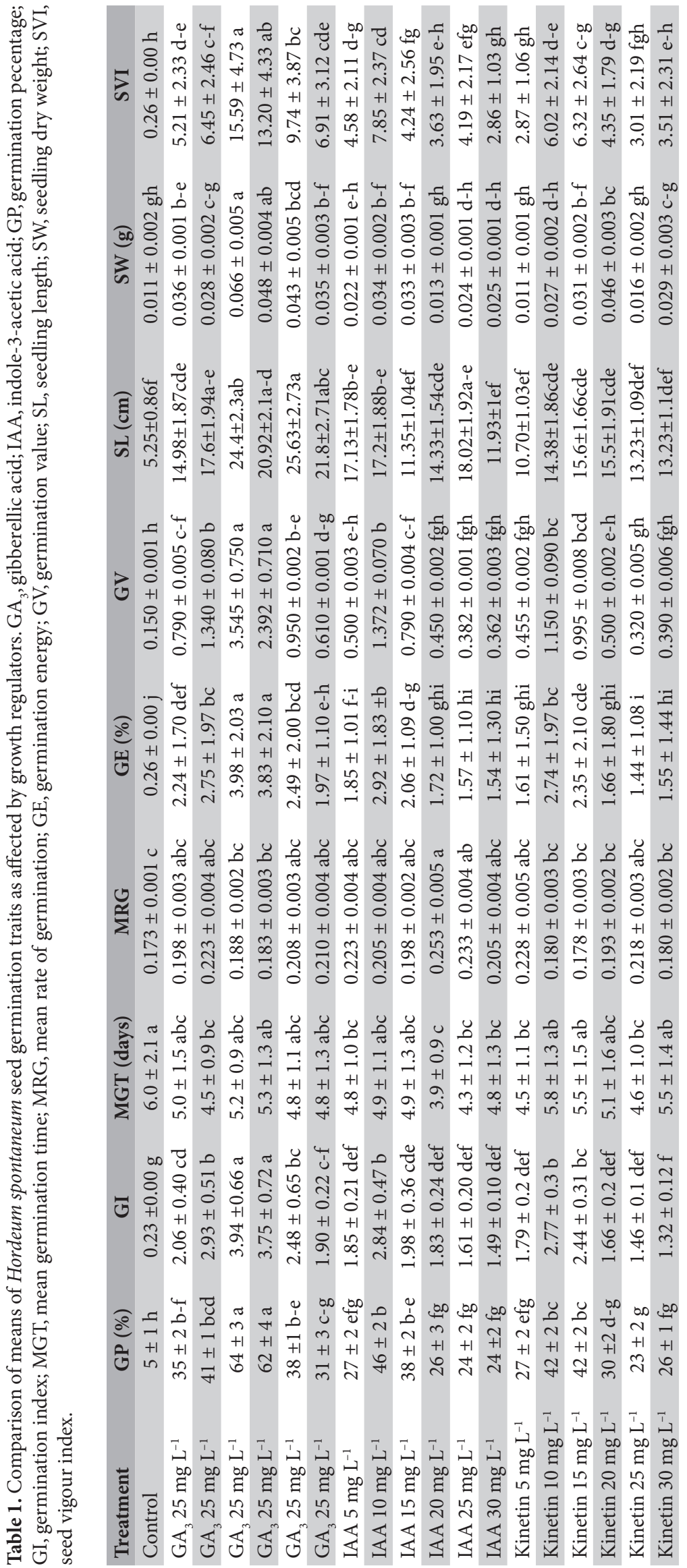

were 75 and $100 \mathrm{mg} \mathrm{L}^{-1}$ in $\mathrm{GA}_{3}$ and $10 \mathrm{mg}$ $\mathrm{L}^{-1}$ in IAA and kinetin. With increasing the concentration of PGR, the GI was decreased, but it was significantly higher that in the control.

There was a a significant difference $(p$ $<0.05)$ for MGT of $H$. spontaneum seeds exposed to different PGRs (Table 1). All PGR concentrations tested shortened the time necessary to start germination; but the effects of $50 \mathrm{mg} \mathrm{L}^{-1} \mathrm{GA}_{3}, 5,20,25$ and $30 \mathrm{mg} \mathrm{L}^{-1}$ IAA and 5 and $25 \mathrm{mg} \mathrm{L}^{-1}$ kinetin treatments significantly differed only from that in the control. The lowest (3.93 day) and highest (6 day) MGT were obtained in $20 \mathrm{mg} \mathrm{L}^{-1}$ IAA and control treatments respectively.

PGRs treatment improved MRG (Table 1). In this case, the highest MRG was obtained when seeds were treated with 20 and 25 mg $\mathrm{L}^{-1}$ IAA. Other treatments although increased MRG, but with no significant ( $p$ $>0.05$ ) difference with the control (Table 1). Generally, IAA was more effective in increasing $\mathrm{MRG}$, compared to $\mathrm{GA}_{3}$ and kinetin (Table 1).

GE improved dramatically in all seeds treated with PGRs (Table 1). The lowest GE (0.26) was observed in the control treatment, while the highest GE (3.98 and 3.83) was recorded in 75 and $100 \mathrm{mg} \mathrm{L}^{-1} \mathrm{GA}_{3}$ treatments, respectively. IAA and kinetin (10 $\left.\mathrm{mg} \mathrm{L}^{-1}\right)$ treatments and 75 and $100 \mathrm{mg} \mathrm{L}^{-1}$ $\mathrm{GA}_{3}$ treatments were suitable doses to obtain maximum rate of $\mathrm{GE}$, compared to other concentrations. In PGR treatments, there was a decreasing trend in GE with increase of PGR concentration.

All concentrations of $\mathrm{GA}_{3}$ treatments were effective in increasing GV, compared to the control (Table 1). Moreover, seeds treated by $\mathrm{GA}_{3}$ at 75 and $100 \mathrm{mg} \mathrm{L}^{-1}$ resulted in significantly higher GE (3.55 and 2.39) than in other treatments. Both IAA and kinetin treatments had significant effect on GV at 10 and $15 \mathrm{mg} \mathrm{L}^{-1}$ concentrations. Other concentrations of IAA and kinetin increased $\mathrm{GV}$, but with no significant difference $(p>$ 0.05 ) from that in the control (Table 1).

$\mathrm{GA}_{3}$ at all used concentrations dramatically increased seedling length, compared to the control (Table 1). IAA at concentrations of 5, 10, 20 and $25 \mathrm{mg} \mathrm{L}^{-1}$ and kinetin at 10, 15 and $20 \mathrm{mg} \mathrm{L}^{-1}$ significantly increased seedling length compared with the control treatment. The highest seedling 
length $(25.63 \mathrm{~mm})$ occurred when seeds were soaked with $125 \mathrm{mg} \mathrm{L}^{-1} \mathrm{GA}_{3}$, and the lowest length $(5.25 \mathrm{~mm})$ for untreated seeds (control).

All concentrations of $\mathrm{GA}_{3}$, except $50 \mathrm{mg} \mathrm{L}^{-1}$, considerably improved seedling dry weight compared with the control (Table 1). Also, all concentrations of IAA (except 10 and 15 $\mathrm{mg} \mathrm{L}^{-1}$ ) and kinetin (except 15 and $20 \mathrm{mg} \mathrm{L}^{-1}$ ) were effective in increasing seedling dry weight. The highest $(0.066 \mathrm{~g})$ and the lowest $(0.011 \mathrm{~g})$ weight were obtained in $75 \mathrm{mg} \mathrm{L}^{-1} \mathrm{GA}_{3}$ and control treatments, respectively.

$\mathrm{GA}_{3}$ at all used concentrations, IAA at concentrations of $5,10,15$ and $25 \mathrm{mg} \mathrm{L}^{-1}$, and kinetin at concentrations 10,15 and $20 \mathrm{mg} \mathrm{L}^{-1}$ dramatically increased SVI, compared with the control treatment. The highest SVI (15.59) was occurred in $75 \mathrm{mg} \mathrm{L}^{-1} \mathrm{GA}_{3}$, and the lowest SVI (0.26) for untreated seeds.

\section{Discussion}

All germination parameters of $H$. spontaneum seeds except mean germination time (MGT) were significantly affected by $\mathrm{GA}_{3}$. Soaking of seeds at all doses of $\mathrm{GA}_{3}$ effectively improved germination percentage (GP), germination index (GI), germination energy (GE), germination value (GV), seedling length and seed vigour index (SVI). $\mathrm{GA}_{3}$ at 50 $\mathrm{mg} \mathrm{L}^{-1}$ significantly shortened the time necessary to start germination and at all concentrations, except $50 \mathrm{mg} \mathrm{L}^{-1}$, increased seedling dry weight. Gibberellic acid can overcome seed dormancy in several types of seeds (Jacobsen et al. 2002; Gubler et al. 2008). In previous studies, the positive effect of gibberellins on improving seed germination in several plants have been shown, including barley (Jacobsen et al. 2002), Vigna mungo and Macrotyloma uniflorum (Chauhan et al. 2009), Teucrium ploium (Kocheki, Azizi, 2006), and Secale montanum (Afrigan et al. 2013).

The GA/ABA balance determines germination and dormancy maintenance in seeds (White et al. 2000; Chibani et al. 2006; Jacobsen et al., 2002). ABA has a positive role in inducing and maintaining dormancy, while GA releases dormancy and stimulates germination (Matilla, MatillaVazquez 2008; Chaudhuri et al. 2013). Embryo elongation requires cell expansion in defined regions of the radicle and lower hypocotyl, which is promoted by GA and inhibited by ABA (Linkies, Leubner-Metzger 2013).

GA promotes seed germination by inhibiting ABA activity and decreasing ABA concentration, via activation of catabolizing enzymes and inhibition of the related biosynthesis pathways (Toyomasu et al. 1994; Atia et al., 2009), as well as by the suppressing effects of excess ABA on embryo expansion (Liu et al. 2013).

GA stimulates the synthesis and production of mannanase (Wang et al. 2005) and hydrolytic enzymes, such as $\alpha$-amylase, which are necessary for germination (Miransaria, Smith 2014). In this case cleared that Gibberellins are able to induce a range of genes, which are necessary for $\alpha$-amylase, protease and glucanase production (Yamaguchi 2008). GA upregulation of photosystem II oxygen production may enhance the efficiency of energy pathways in plant tissues. This may also be the case in germinating seedlings (Miransaria, Smith 2014).

We showed that IAA at all concentrations was significantly effective for increasing GP, GI and GE. It also improved other germination parameters, depending on the used dose. The role of auxin in germination has been described by many authors. Auxin by itself may not be a necessary hormone for seed germination, but it interferes with other PGPs like gibberellins and ethylene, and may influence the processes of seed germination and establishment (Fu, Harberd 2003; Chiwocha et al. 2005). IAA can stimulate the production of ethylene (Arteca, Arteca 2008) and ethylene plays a positive role in dormancy release and seed germination (Hermann et al. 2007; Finkelstein et al. 2008; Chaudhuri et al. 2013). IAA can affect seed germination by altering the activity of enzymes; for example, in germinating pea seeds, increase of glyoxalase I activity by IAA leads in higher rates of cell growth and development (Miransaria, Smith 2014). Furthermore, auxin is necessary for the growth of young seedlings (Hentrich et al. 2013).

In contrast to the above, some reports have suggested the potential involvement of auxin in maintenance of seed dormancy in Arabidopsis (Brady et al., 2003; Liu et al., 2007; Liu et al 2013) and also in delay of seed germination of wheat (Morris et al., 1988; Ramaih et al., 2003). Auxin promotes dormancy and inhibits germination by enhancing $\mathrm{ABA}$ action, but together auxin and $\mathrm{ABA}$ act synergistically to inhibit seed germination and the auxinmediated inhibition of seed germination is dependent on ABA (Liu et al. 2013). As a result, an equal amount of IAA did not inhibit seed germination in the absence of $A B A$, but auxin can influence seed germination when $\mathrm{ABA}$ is present (Brady et al. 2003). Thus, it seems that the mechanism of auxin function in seed germination is not well understood yet.

As previously mentioned, seed treatment with all concentrations of kinetin considerably promoted GP, GA and GE, compared with the control. Furthermore, it also improved other evaluated traits (except MRG) depending on the applied dose. Other studies showed that cytokinins have stimulatory effects on the seed germination of a wide range of plant species (Jones, Stoddart 1977; Thomas 1997). In Gossypium barbadense treatment with kinetin improved seed viability and seedling vigour, as shown by increased length of hypocotyl, radicle and the entire seedling, as well as seedling fresh weight (Sawana et al. 2000). Kinetin application can be useful for breaking the strong dormancy commonly observed in the dehusked seeds of indica rice (Miyoshi, Sato 1997). Cytokinins are able to promote seed germination especialy under stress conditions (Peleg, Blumwald 2011). Cytokinins and their negative interaction 
with $\mathrm{ABA}$ can positively regulate seed germination and break seed dormancy (Miransaria, Smith, 2014).

In conclusion, our results demonstrated that all PGRs, depending on the used concentration, improved the seed germination in Hordeum spontaneum. Overall, $\mathrm{GA}_{3}$ especially at $75 \mathrm{mg} \mathrm{L}^{-1}$ and followed by $100 \mathrm{mg} \mathrm{L}^{-1}$, was most effective in improving seed germination parameters, except MGT, which was not influenced by $\mathrm{GA}_{3}$. Thus, the present study recommends that application of PGRs like $\mathrm{GA}_{3}$, IAA and kinetin can be useful for overcoming dormancy and in promotion rapid germination in Hordeum spontaneum.

\section{References}

Ahmadloo F., Tabari M., Rahmani A., Yousefzadeh H., RazaghZadeh M. 2009. Effect of soil composition on seed germination of Pinus halepensis Mill. J. Iran. Forest Poplar Res. 17: 394-403. (in Persian)

Afrigan A., Javdani Z., Jahantab E., Jahanbin R., Bahari A.A. 2013. The effect of plant hormone gibberellic acid on germination indices Secale montanum in vitro and pot experiments under drought conditions. Ann. Biol. Res. 4: 1-9.

Arteca R., Arteca J. 2008. Effects of brassinosteroid, auxin, and cytokinin on ethylene production in Arabidopsis thaliana plants. J. Exp. Bot. 59: 3019-3026.

Atia A., Debez A., Barhoumi Z., Smaoui A., Abdelly C. 2009. ABA $\mathrm{GA}_{3}$, and nitrate may control seed germination of Crithmum maritimum (Apiaceae) under saline conditions. C. R. Biol. 332: 704-710.

Bradford K., Côme D., Corbineau F. 2007. Quantifying the oxygen sensitivity of seed germination using a population-based threshold level. Seed Sci. Res. 17: 33-43.

Benech-Arnold R.L., Sanches R.A., Forcella F., Kruk B.C., Chesa C.M. 2000. Environmental control of dormancy in weed seed banks. Field Crop Res. 67: 105-122.

Brady S.M., Sarkar S.F., Bonetta D., McCourt P. 2003. The Abscisic acid insensitive 3 ( $\mathrm{ABI} 3$ ) gene is modulated by farnesylation and is involved in auxin signaling and lateral root development in Arabidopsis. Plant J. 34: 67-75.

Chaudhuri A., Singh K.L., Kar R.K. 2013. Interaction of hormones with reactive oxygen species in regulating seed germination of Vigna radiata (L.) Wilczek. J. Plant Biochem. Physiol. 1: 103.

Chauhan J.S., Tomar Y.K., Indrakumar N., SinghS A., Debarati. 2009. Effect of growth hormones on seed germination and seedling growth of black gram and horse gram. J. Am. Sci. 5: 79-84.

Chibani K., Ali-Rachedi S., Job C., Job D., Jullien M., Grappin P. 2006. Proteomic analysis of seed dormancy in Arabidopsis. Plant Physiol. 142: 1493-1510.

Chiwocha S.D., Cutler A.J., Abrams S.R., Ambrose S.J., Yang J. 2005. The etr1-2 mutation in Arabidopsis thaliana affects the abscisic acid, auxin, cytokinin and gibberellin metabolic pathways during maintenance of seed dormancy, moistchilling and germination. Plant J. 42: 35-48.

Evenari M., Shanan L., Tadmor N. 1982. The Negev. The Challenge of a Desert. $2^{\text {nd }}$ Edition. Harvard University Press, Cambridge, 437pp.

Finkelstein R., Reeves W., Ariizumi T., Steber C. 2008. Molecular aspects of seed dormancy. Annu. Rev. Plant Biol. 59: 387-415.

Fu Y.B., Horbach C. 2012. Genetic diversity in a core subset of wild barley germplasm. Diversity 4: 239-257.

$\mathrm{Fu}$ X., Harberd N.P. 2003. Auxin promotes Arabidopsis root growth by modulating gibberellin response. Nature 421: 740-743.

Ghalmbaz S., Fateh E. 2011. Effects of allelopathic weed growth potential of the ring of wheat, oats, canola, wild mustard. The first national conference on new topics in agriculture, Saveh, Iran.

Gholinejad E. 2012. Effect of salinity on seed germination of wheat genotypes. Seed Sci Res. 1: 14-21. /in Persian/

Gubler F., Trijntje H., Peter W., John J. 2008. Regulation of dormancy in barley by blue light and after-ripening: effects on ebscisic ecid and gibberellin metabolism. Plant Physiol. 147: 886-896

Gutterman Y., Corbineau F.,Come D. 1996. Dormancy of Hordeum spontaneum caryopses from a population on the Egev Desert Highlands. J. Arid. Environ. 33: 337-345.

Gutterman Y., Gozlan S. 1998. Amounts of winter or summer rain triggering germination and 'the point of no return' of seedling desiccation tolerance, of some Hordeum spontaneum local ecotypes in Israel. Plant Soil. 204: 223-234.

Gutterman Y. 1996. Temperatures during storage, light and wetting, affecting caryopses germinability of Schismus arabicus a common desert annual grass. J. Arid. Environ. 33: 73-85.

Hentrich M., Boettcher C., Duchting P. 2013. The jasmonic acid signaling pathway is linked to auxin homeostasis through the modulation of YUCCA8 and YUCCA9 gene expression. Plant J. 74: 626-637.

Hermann K., Meinhard J., Dobrev P., Linkies A., Pesek B., Heß B., Machackova I., Fischer U., Leubner-Metzger G. 2007. 1-Aminocyclopropane-1-carboxylic acid and abscisic acid during the germination of sugar beet (Beta vulgaris L.) - a comparative study of fruits and seeds. J. Exp. Bot. 58: 30473060 .

Jacobsen J.V., Pearce D.W., Poole A.T., Pharis R.P., Mander L.N. 2002. Abscisic acid, phaseic acid and gibberellin contents associated with dormancy and germination in barley. Physiol. Plant. 115: 428-441

Jones R.L., Stoddart J.L. 1977. Gibberellin and seed germination. In: Khan A.A. (ed) The Physiology and Biochemistry of Seed Dormancy and Germination. Kluwer Academic Press, Amsterdam, pp. 77-110.

Khoocheki A., Azizi G. 2005. Effect of different treatments on breaking dormancy of Teucrium polium. J. Iran. Field Crop Res. 1: 81-88.

Kucera B., Cohn M.A., Leubner-Metzger G. 2005. Plant hormone interactions during seed dormancy release and germination. Seed Sci. Res. 15: 281-307.

Linkies A., Leubner-Metzger G. 2012. Beyond gibberellins and abscisic acid: how ethylene and jasmonates control seed germination. Plant Cell Rep. 31: 253-270.

Liu A., Gao F., Kanno Y., Jordan M.C., Kamiya Y. 2013. Regulation of wheat seed dormancy by after-ripening is mediated by specific transcriptional switches that induce changes in seed hormone metabolism and signaling. PLOS One 8: e56570.

Liu P.P. 2007. Repression of auxin response factor 10 by microRNA160 is critical for seed germination and postgermination stages. Plant J. 52: 133-146.

Matilla A.J., Matilla-Vazquez M.A. 2008. Involvement of ethylene in seed physiology. Plant Sci. 175: 87-97

Miransari M., Smith D.L. 2014. Plant hormones and seed germination. Environ. Exp. Bot. 99: 110-121

Miyoshi K., Sato T. 1997. The effects of kinetin and gibberellin 
on the germination of dehusked seeds of indica and japonica rice (Oryza sativa L.) under anaerobic and aerobic conditions. Ann Bot. 80: 479-483.

Morris C.F., Mueller D.D., Faubion J.M., Paulsen G.M. 1988. Identification of L-tryptophan as an endogenous inhibitor of embryo germination in white wheat. Plant Physiol. 88: 435440.

Mousavizadeh S.J., Sedaghathoor S., Rahimi A., Mohammadi H. 2013. Germination parameters and peroxidase activity of lettuce seed under stationary magnetic field. Int. J. Biosci. 3: 199-207.

Nevo E. 1992. Origin, evolution, population genetics and resources for breeding of wild barley, Hordeum spontaneum, in the Fertile Crescent. In: Shewry P.R. (ed) Barley Genetics, Biochemistry, Molecular Biology and Biotechnology. CAB International, Wallingford, pp. 19-43.

Norimoto M. 2014.Plant growth hormone cytokinins control the crop seed yield. Am. J. Plant Sci. 5: 2178-2187.

Peleg Z., Blumwald E. 2011. Hormone balance and abiotic stress tolerance in crop plants. Curr. Opin. Plant Biol. 14: 290-295.

Rahimi A.R., Mousavizadeh S.J., Mohammadi H., Rokhzadi A., Majidi M., Amini S. 2013. Allelopathic effect of some essential oils on seed germination of Lathyrus annuus and Vica villosa. J. Biol. Environ. Sci. 3: 67-73.

Ramaih S., Guedira M., Paulsen G.M. 2003.Relationship of indole acetic acid and tryptophan to dormancy and preharvest sprouting of wheat. Funct. Plant Biol. 30: 939-945.

Ramana S., Biswas A.K., Kundu S., Saha J.K, Yadava R.B.R. 2002.
Effect of distillery effluent on seed germination in some vegetable crops. Bioresour. Technol. 82: 273-275.

Shahmoradi S.H., Cheychi M.R., Mozafari J., Mazaheri D., Sharifzadeh F. 2013. Break dormancy in Hordeum spontaneum. J. Plant Biol. Iran. 27: 872-884. /in Persian/

Thomas T.H. 1977. Cytokinins, cytokinin-active compounds and seed germination. In: Khan A.A. (ed) The Physiology and Biochemistry of Seed Dormancy and Germination. Kluwer Academic Press, Amsterdam, pp. 111-144.

Toyomasu T., Yamane H., Murofushi N., Inoue Y. 1994. Effects of exogenously applied gibberellin and red light on the endogenous levels of abscisic acid in photoblastic lettuce seeds. Plant Cell Physiol. 35: 127-129.

Wang A.X., Wang X.F., Ren Y.F., Gong X.M., Bewley J.D. 2005. Endo-b-mannanase and $\mathrm{b}$-mannosidase activities in rice grains during and following germination, and the influence of gibberellin and abscisic acid. Seed Sci. Res. 15: 219-227.

Wang M. 1997. The role of abscisic acid in the regulation of barley grain germination. Seed Sci. Technol. 25: 67-74.

Wang Y.H., Irving H.R. 2011. Developing a model of plant hormone interactions. Plant Signal. Behav. 6: 494-500.

White C.N., Proebsting W.M., Hedden P., Rivin C.J. 2000. Gibberellins and seed development in maize. I. Evidence that gibberellin/abscisic acid balance governs germination versus maturation pathways. Plant Physiol. 122: 1081-1088.

Yamaguchi S. 2008. Gibberellin metabolism and its regulation. Annu. Rev. Plant Biol. 59: 225-251. 